\title{
PENINGKATAN KESEJAHTERAAN PETANI MELALUI PEMANFAATAN LIMBAH SAPI DI DESA JATITENGAH, SUGIHWARAS BOJONEGORO
}

\section{IMPROVING FARMER WELFARE THROUGH UTILIZATION OF COW DIRT IN JATITENGAH SUGIHWARAS BOJONEGORO}

\author{
Shochrul Rohmatul Ajija ${ }^{1}$, Rumayya ${ }^{2}$, M. Khoerul Mubin ${ }^{3}$, Akhmad Jayadi $^{4}$ \\ 1,2,3,4 Departemen Ilmu Ekonomi, Fakultas Ekonomi dan Bisnis, Universitas Airlangga \\ email: shochrul-r-a@feb.unair.ac.id
}

\begin{abstract}
Jatitengah Village is one of the villages located in Sugihwaras District, Bojonegoro Regency. Currently, the main problem facing Jatitengah village is the problem of cow manure waste. Farmers do not have the ability and skills to process cow dung waste, and so far they have used cow dung as organic fertilizer which is only left in the open. This is less effective to do, because it can cause unpleasant odors and cause global warming. Seeing these conditions, it is very necessary to apply science and technology for the use of cow dung, so that farmers can take advantage of cow dung independently, especially making alternative energy in the form of biogas. The results achieved in this community service program include the construction of a biogas installation, the implementation of training in processing cow waste into biogas, training in maintaining biogas installations, and installing a biogas stove and carrying out the distribution of biogas to residents' homes. In addition, farmers and / or cattle breeders become more aware of the process of making biogas, by participating in training or on-site observation. The community service program implemented in Jatitengah village has succeeded in producing biogas as an alternative energy for farmers and/ or cattle breeders. Thus, farmers can use biogas as a substitute for firewood and LPG gas, and in the end the welfare of farmers in Jatitengah village can be achieved.
\end{abstract}

Keywords: Cow Manure Waste, Farmer Welfare, Alternative Energy Sources

\begin{abstract}
abstrak
Desa Jatitengah merupakan salah satu desa yang terletak di Kecamatan Sugihwaras, Kabupaten Bojonegoro. Saat ini, masalah utama yang dihadapi desa Jatitengah adalah masalah limbah kotoran ternak sapi. Para petani belum mempunyai kemampuan dan keterampilan mengolah limbah kotoran sapi, dan selama ini petani memanfaatkan limbah kotoran sapi sebagai pupuk organik yang hanya dibiarkan di tempat terbuka. Hal ini kurang efektif untuk dilakukan, karena dapat menimbulkan bau tidak sedap dan menyebabkan pemanasan global. Melihat kondisi tersebut, sangat perlu adanya penerapan Iptek pemanfaatan limbah kotoran sapi, agar petani dapat memanfaatkan limbah kotoran sapi secara mandiri, terutama menjadikan energi alternatif berupa biogas. Hasil yang dicapai pada program pengabdian masyarakat ini antara lain terbangunnya instalasi biogas, terlaksananya pelatihan dalam mengolah limbah sapi menjadi biogas, pelatihan dalam merawat instalasi biogas, dan terpasangnya kompor biogas serta terlaksananya penyaluran biogas ke rumah warga. Selain itu, petani dan atau peternak sapi menjadi lebih paham akan proses pembuatan biogas, dengan cara mengikuti pelatihan atau pengamatan secara langsung di lokasi. Program pengabdian masyarakat yang dilaksanakan di desa Jatitengah telah berhasil menghasilkan biogas sebagai energi alternatif bagi petani dan atau peternak sapi. Dengan demikian, petani dapat memanfaatkan biogas sebagai pengganti kayu bakar dan gas LPG, dan pada akhirnya kesejahteraan petani di desa Jatitengah dapat tercapai.
\end{abstract}

Kata Kunci: Limbah Kotoran Sapi, Kesejahteraan Petani, Sumber Energi Alternatif 
Shochrul Rohmatul Ajija, dkk.: Peningkatan Kesejahteraan Petani Melalui Pemanfaatan Limbah Sapi di Desa Jatitengah, Sugihwaras Bojonegoro

\section{PENDAHULUAN}

Pengelolaan sampah merupakan permasalah serius yang dihadapi bangsa Indonesia, karena jumlah sampah terus bertambah seiring dengan peningkatan jumlah penduduk di Indonesia (Mahyudin 2017). Berdasarkan realita tersebut, strategi pengelolaan sampah sebaiknya diarahkan untuk pengurangan sampah, untuk mengurangi ketergantungan terhadap lahan yang semakin berkurang seiring bertambahnya jumlah penduduk, Kholil (2009:46) dalam Suyanto dkk (2015). Pengelolaan sampah tersebut diharapkan dapat mengurangi permasalahan yang ditimbulkan oleh sampah terhadap lingkungan hidup dan kesehatan masyarakat serta menjadikan sampah sebagai sumber daya (Pratama dan Yusri 2018).

Salah satu jenis sampah yaitu Biomassa. Biomassa adalah bahan organik yang dihasilkan melalui proses foto sintetik, baik berupa produk maupun buangan. Contoh biomassa antara lain adalah semua bagian tanaman, limbah makanan, limbah pertanian, limbah hutan, tinja dan kotoran ternak. Sumber energi biomassa mempunyai kelebihan yaitu merupakan sumber energi yang dapat diperbaharui sehingga dapat menyediakan sumber energi secara berkesinambungan (Kamal dkk. , 2017). Salah satu energi berkesinambungan yang dapat dihasilkan dari biomassa yaitu biogas (Yanti dan Arlius, 2018). Daerah pedesaan memiliki potensi yang tinggi dalam memanfaatkan biomassa menjadi biogas, terutama biogas yang diperoleh dari kotoran sapi karena pada mayoritas peternakan berada di pedesaan. Seekor sapi akan dapat menghasilkan 0,3m biogas per hari (Choirun dan Setiawan, 2015).

Desa Jatitengah merupakan salah satu desa di Kecamatan Sugihwaras, Kabupaten Bojonegoro. Mayoritas penduduknya bermata pencaharian sebagai petani. Selain bermata pencaharian sebagai petani, masyarakat Desa Jatitengah juga beternak sapi sebagai usaha sampingan para petani. Berdasarkan hasil analisis mengenai usaha ternak sapi di desa Jatitengah, secara ekonomis belum menguntungkan, karena mayoritas petani belum memperhitungkan biaya akan kebutuhan pakan beserta tenaga. Sebagian besar petani di desa Jatitengah menganggap beternak sapi tersebut sebagai Rajakaya (status sosial masyarakat), usaha sampingan apabila terdapat kebutuhan yang mendesak, sebagai tabungan, dan lain sebagainya. Sehingga, dalam sektor peternakan di desa Jatitengah belum mampu dikembangkan secara optimal dan berperan dalam pemberdayaan ekonomi masyarakat.

Berdasarkan pengamatan, penerimaan peternak hanya meliputi penjualan ternak sapi sendiri dan kenaikan nilai ternak dalam setahun. Sedangkan untuk mengoptimalkan peran ternak terhadap pendapatan masih ada kotoran atau limbah sapi yang dapat dimanfaatkan menjadi produk yang bernilai ekonomis tinggi. Akan tetapi selama ini para petani di Desa Jatitengah memanfaatkan limbah sapi sebagai pupuk biasa yang hanya dibiarkan di tempat terbuka. Kotoran ternak bila tidak dimanfaatkan dan tidak dikelola dengan baik dapat menurunkan mutu lingkungan (kesehatan) dan mengganggu kenikmatan hidup masyarakat (Hastuti, 2009). Selain pupuk organik yang dibiarkan di tempat terbuka dapat pemanasan global (Noerhayati and Lesmanah, 2018).

Selain itu, masyarakat Desa Jatitengah belum memiliki pengetahuan mengenai pemanfaatan limbah sapi yang sebenarnya dapat dijadikan sebagai bahan baku untuk menghasilkan energi terbarukan pengganti Bahan Bakar Minyak (BBM) dan kayu, 
karena selama ini masyarakat Desa Jatitengah juga sangat tergantung pada BBM dan kayu untuk keperluan memasak. Sehingga hal tersebut akan berdampak terhadap pendapatan dari masyarakat sendiri, di mana selalu membeli elpiji dalam kegiatan memasak. Dengan mengolah limbah sapi menjadi biogas, maka akan dapat menjadi sumber energi alternatif masyarakat (Hamri dkk., 2018).

Di samping itu, dalam proses menghasilkan energi terbarukan berupa biogas, akan dihasilkan pula sisa kotoran ternak yang dapat langsung dimanfaatkan sebagai pupuk organik pada tanaman pertanian, di mana limbah biogas sendiri adalah kotoran ternak yang telah hilang gasnya yang merupakan pupuk organik sangat kaya akan unsur-unsur yang dibutuhkan oleh tanaman. Dalam hal ini sisa limbah kotoran sapi tersebut dapat dijadikan sebagai pupuk alternatif untuk mempertahankan produksi tanaman (Rahayu dkk, 2009).

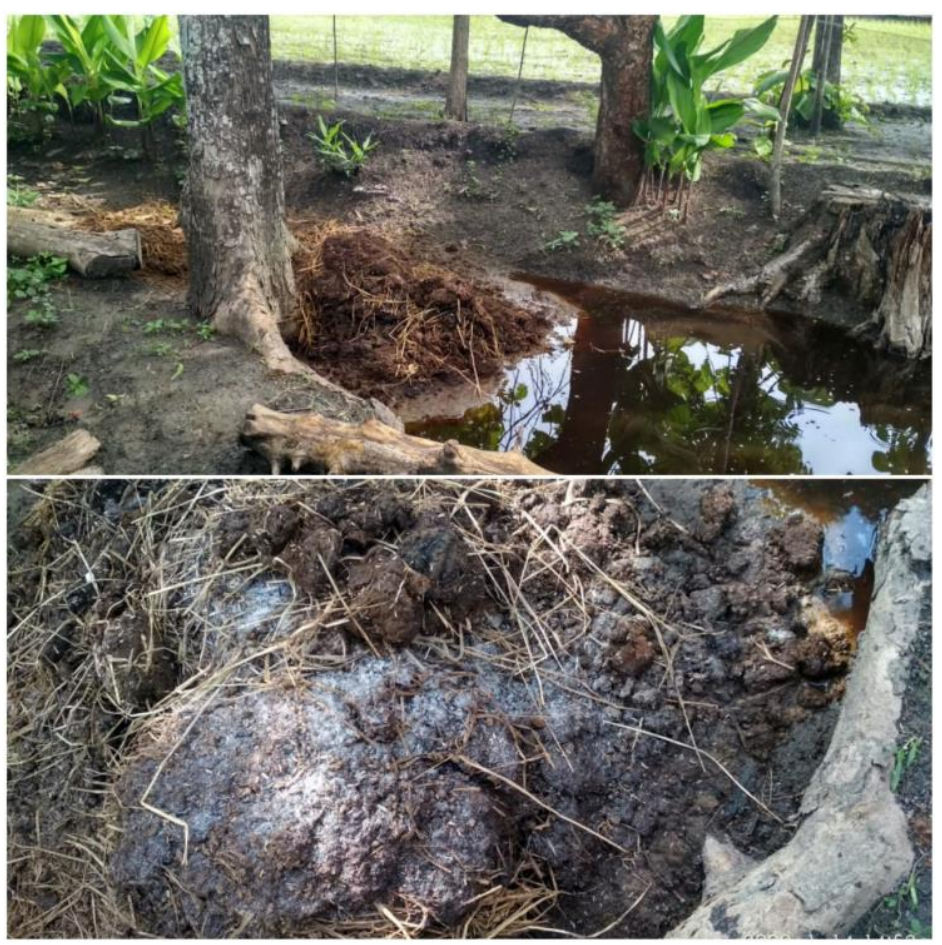

Sumber: Dokumentasi Pribadi

\section{Gambar 1. Limbah Kotoran Sapi Petani Desa Jatitengah}

Gambar diatas merupakan limbah sapi yang terlihat menumpuk dan berserakan di salah satu lingkungan rumah warga desa Jatitengah. Limbah sapi tersebut jika tidak dimanfaatkan dan tidak dikelola dengan baik dapat menurunkan mutu lingkungan (kesehatan), yang dapat menimbulkan pencemaran terhadap air, tanah, dan udara, serta dapat mengganggu kenyamanan hidup masyarakat. Selain itu, limbah sapi yang menumpuk secara alami juga akan menghasilkan gas methana $(\mathrm{CH} 4)$ yang merupakan gas penyumbang terbesar pada efek rumah kaca.

Untuk mengatasi masalah tersebut, penggunaan limbah sapi sebagai bahan biogas merupakan pilihan yang tepat, dengan menggunakan teknologi yang cukup sederhana limbah sapi yang hanya mencemari lingkungan dapat diubah menjadi sumber energi 
terbarukan yang bisa dimanfaatkan oleh masyarakat Desa Jatitengah. Berdasarkan latar belakang diatas, pemanfaatan limbah sapi menjadi biogas tampaknya menjadi suatu keharusan, menyangkut limbah sapi sebagai sumber energi terbarukan yang murah dan dapat meningkatkan kesejahteraan petani Desa Jatitengah.

\section{METODE PENGABDIAN MASYARAKAT}

Terdapat lima tahapan pelaksanaan program pengabdian masyarakat ini. Hal ini tampak pada diagram alur berikut:

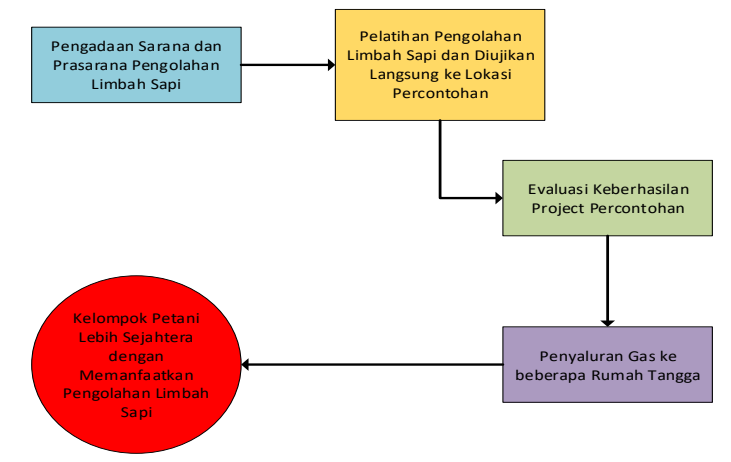

\section{Gambar 2. Tahapan Pelaksanaan Kegiatan}

Secara lebih detail, tahapan pelaksanaan kegiatan pengabdian masyarakat ini adalah sebagai berikut:

1. Pengadaan Sarana dan Prasarana Pengolahan Limbah Sapi

Pada tahap ini, tim pengabdian masyarakat bekerja sama dengan mitra yang telah ahli dalam mengolah limbah sapi, yaitu Bapak Irvan Adhin Cholilie. Agar pengolahan limbah sapi dapat optimal, maka beberapa instalasi yang diperlukan adalah penampungan limbah, lubang inlet, tangki pencerna, lubang pengeluaran/outlet, tabung penampungan gas, saluran gas, dan manometer, satu set pemanfaatan biogas (kompor, lampu, genset), kolam oksidasi. pengolahan limbah padat, dan pengolahan limbah cair.

2. Pelatihan Pengolahan Limbah Sapi dan Diujikan Langsung ke Lokasi Percontohan

Pada tahap ini, tim pengabdian masyarakat mengkoordinir kelompok petani dan menentukan lokasi percontohan untuk pemasangan instalasi pengolahan limbah sapi. Secara garis besar, proses pengolahan limbah sapi ditunjukkan melalui gambar berikut:



Gambar 3. Proses Pengolahan Limbah Sapi

Sumber: http://unggulwidyoseno12.blogspot.com/ 
3. Evaluasi Keberhasilan Project Percontohan

Pada tahap ini, hasil pemasangan instalasi pada tahap ke 2 akan dievaluasi dan diuji keberhasilannya serta mencari strategi bagaimana agar hasil produksi dapat maksimal.

4. Penyaluran Gas ke Beberapa Rumah Tangga

Keberhasilan pada tahap 3 akan dilanjutkan pada pemasangan pipa gas pada beberapa rumah tangga petani. Pelatihan kepada ibu rumah tangga petani juga dilakukan untuk proses pemeliharaan instalasi.

Dengan empat tahapan di atas, diharapkan agar para petani dapat lebih sejahtera baik dari aspek peningkatan ekonomi maupun kesehatan lingkungan. Para petani dapat lebih berhemat dengan menekan pengeluaran gas elpiji maupun penggunaan kayu bakar. Jika masalah limbah sapi terselesaikan dengan baik, maka para petani juga tidak enggan memelihara sapi sebagai penunjang perekonomian keluarga selain dari aktivitas pertanian di sawah.

\section{HASIL DAN PEMBAHASAN}

Berdasarkan metode pelaksanaan, kegiatan program pengabdian masyarakat ini dilaksanakan dengan beberapa tahapan. Tahap pertama yang telah dilakukan adalah tahap koordinasi. Tahap koordinasi dilaksanakan secara bertahap dan rutin agar dalam pelaksanaan kegiatan berjalan dengan lancar dan mengantisipasi ketika terjadi kesalahpahaman. Koordinasi tersebut melibatkan beberapa mitra, yaitu pertama Koperasi BMT Muda sebagai pelaksana dalam pengelolaan keuangan, agar kegiatan pembangunan instalasi biogas di desa Jatitengah dapat bermanfaat dan tersalurkan oleh beberapa rumah tangga. Koperasi BMT Muda melakukan koordinasi terkait sistem iuran yang dilakukan masyarakat sekitar untuk pengadaan pipa. Kedua, mitra yang terlibat adalah Koperasi Peternakan Sapi Perah (KPSP) Setia Kawan NongkojajarPasuruan sebagai penanggung jawab atas tenaga ahli dalam pembangunan instalasi biogas. Selain itu, terdapat juga mahasiswa Ilmu Ekonomi Universitas Airlangga yang turut membantu koordinasi dengan masyarakat, memberikan penjelasan kepada masyarakat terkait tujuan kegiatan, tata cara pemanfaatan limbah kotoran sapi menjadi energi alternatif biogas, hingga membantu edukasi kepada masyarakat dalam mengolah biogas secara mandiri. Koordinasi oleh tim mulai dari awal hingga akhir dilakukan secara daring dengan mempersiapkan semua hal dalam pembangunan instalasi biogas, mengingat keterbatasan mobilitas saat ini yang masih menjadi persoalan akibat adanya pandemi COVID-19. Namun, kegiatan ini dipastikan berjalan dengan baik dan sesuai capaian.

Tahap kedua sebelum pengadaan sarana dan prasarana pengolahan limbah sapi adalah sosialisasi kepada masyarakat. Kegiatan sosialisasi dilaksanakan pada hari Minggu, 9 Agustus 2020, yang diikuti oleh perwakilan masyarakat petani sekaligus peternak sapi yaitu Bapak Madi'in dengan Bapak Hariyanti dan Bapak Sholihin selaku mitra yang ahli dalam mengolah limbah sapi. Kegiatan sosialisasi ini ditujukan agar masyarakat yang memiliki ternak sapi menjadi lebih terbuka dalam memanfaatkan kotoran sapi sebagai salah satu bahan baku pembuatan biogas, serta melakukan survei langsung ke lokasi untuk kemudian dilakukan pengukuran lahan. Selain itu, masyarakat bersama mitra yang ahli dalam mengolah limbah sapi juga melakukan koordinasi terkait pelaksanaan kegiatan, seperti halnya pembelian alat dan bahan yang dibutuhkan, serta penyediaan tempat tinggal untuk para tukang. 


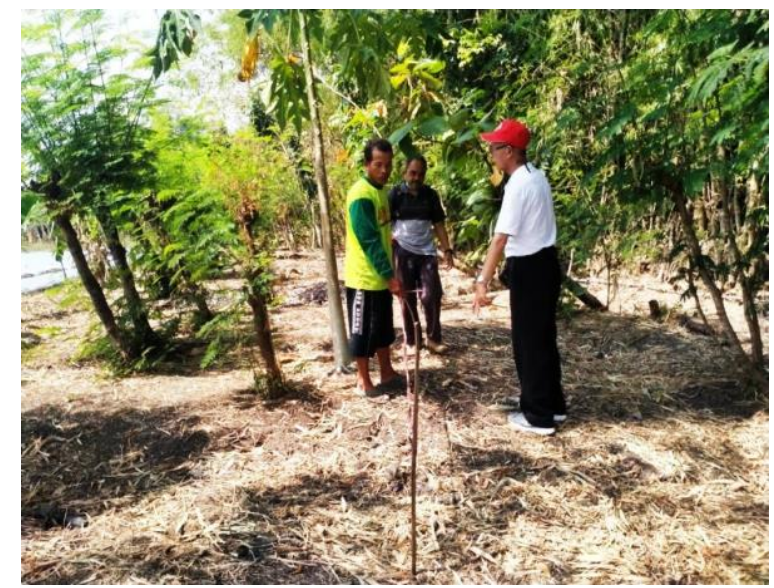

Sumber: Dokumentasi Pribadi

\section{Gambar 4. Pengukuran Lahan untuk Pembuatan Digester Biogas}

Berdasarkan gambar tersebut, masyarakat bersama mitra yang ahli dalam mengolah limbah sapi sedang melakukan pengukuran lahan sebagai proses awal diadakannya sarana dan prasarana pengolahan limbah sapi. Tujuan dari pengukuran lahan yaitu agar masyarakat lebih mudah dalam membangun digester biogas. Digester biogas dibuat secara permanen dengan ukuran diameter $3.00 \mathrm{~m}$ dan kedalaman $1.70 \mathrm{~m}$. Menurut Bapak Sholihin selaku ahli dalam mengolah limbah sapi, digester biogas di sini merupakan bangunan utama dari instalasi biogas, dan pada bagian atas digester dibuat dalam bentuk kubah (setengah lingkaran) yang berfungsi sebagai penampung gas dari hasil campuran antara kotoran sapi dengan air. Sketsa digester biogas beserta komponennya yang harus dibangun oleh masyarakat adalah sebagai berikut:

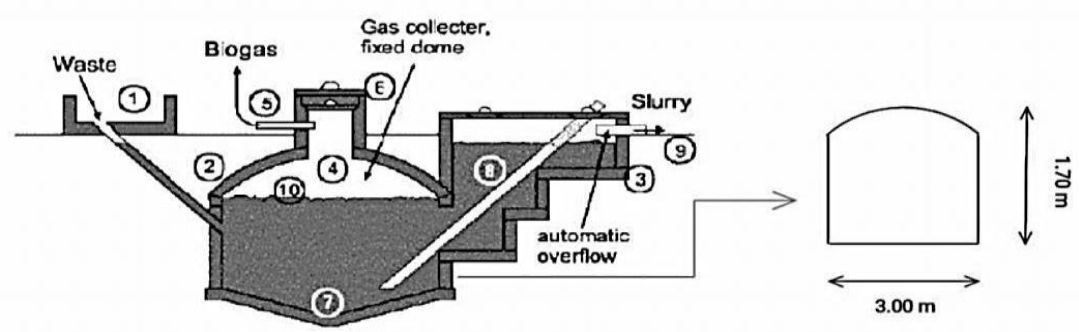

Sumber: Instalasi Biogas, 2016

Keterangan gambar:

\section{Gambar 5. Sketsa Digester Biogas dan Komponennya}

1. Inlet (Inlet (bak pencampur antara kotoran sapi dan air, dengan sambungan pipa inlet ke digester)

2. Digester

3. Bak penampung lumpur sisa fermentasi (sludge)

4. Penampung gas (kubah)

5. Pipa biogas

6. Penutup digester

7. Lumpur biogas

8. Outlet

Berdasarkan sketsa tersebut, ukuran digester disesuaikan dengan luas lahan yang dimiliki masyarakat dan jumlah limbah kotoran sapi yang dihasilkan setiap hari. 
Sebagai tambahan, terdapat juga informasi dasar mengenai ukuran-ukuran digester atau reaktor biogas. Tabel yang menunjukkan kapasitas digester atau reaktor yang dapat ditetapkan berdasarkan ketersediaan bahan baku (kotoran sapi) sebagai berikut:

Tabel 1. Kapasitas Produksi Gas

\begin{tabular}{ccccc}
\hline No. & $\begin{array}{c}\text { Kapasitas } \\
\text { tempat } \\
\text { pengolahan* } \\
\left.\mathbf{( m}^{\mathbf{3}}\right)\end{array}$ & $\begin{array}{c}\text { Kotoran hewan } \\
\text { yang dibutuhkan } \\
\text { per hari }(\mathbf{k g})\end{array}$ & $\begin{array}{c}\text { Jumlah ternak } \\
\text { yang } \\
\text { dibutuhkan }\end{array}$ & $\begin{array}{c}\text { Kayu bakar yang } \\
\text { dapat dihemat } \\
\text { perhari (kg) }\end{array}$ \\
\hline 1. & 4 & $20-40$ & $3-4$ & $20-40$ \\
2. & 6 & $40-60$ & $5-6$ & $40-60$ \\
3. & 8 & $60-80$ & $7-8$ & $60-80$ \\
4. & 10 & $80-100$ & $9-10$ & $80-100$ \\
5. & 12 & $100-120$ & $11-12$ & $100-120$ \\
\hline
\end{tabular}

*Kapasitas tempat pengolahan artinya adalah volume digester biogas dan kubah penyimpanan gas

Sumber: Model Instalasi Biogas Indonesia, 2010

Adapun dalam pembangunan instalasi biogas terdapat beberapa proses yang harus dilakukan, seperti halnya pembuatan digester yang mencakup proses penggalian, pengecoran, pemasangan dinding digester, pelicinan dinding dan lantai, bekisting (pencetakan), pemasangan pipa gas, hingga terbentuknya digester dan semua komponennya. Proses-proses tersebut disajikan pada Gambar 6, 7, 8, 9, 10, 11, 12, dan 13.
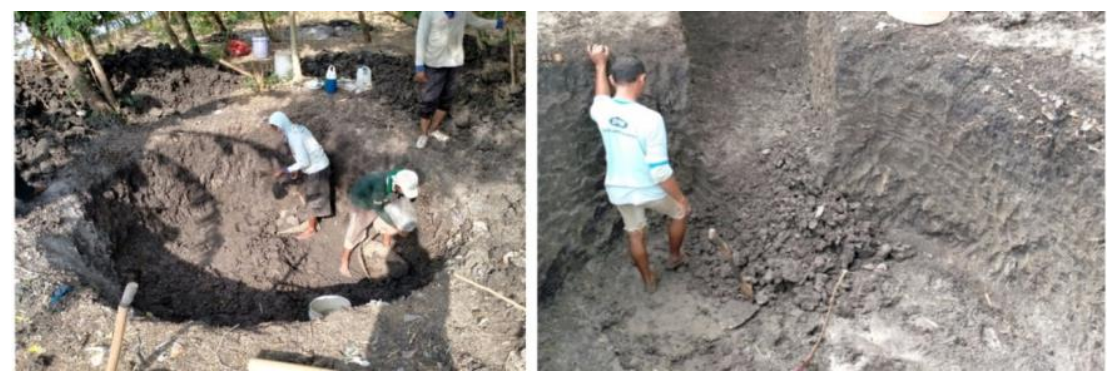

Gambar 6. Proses Penggalian Lubang Digester

Sumber: Dokumentasi Pribadi

Pada Gambar 6, dapat dilihat proses penggalian lubang digester. Dalam proses penggalian lubang alat yang harus tersedia antara lain linggis, cangkul, keranjang, dan karung. Penggalian lubang digester dilakukan secara vertikal, sisi-sisi lubang dipastikan dalam keadaan lurus agar lebih memudahkan konstruksi dinding digester selanjutnya. Pada bagian dasarnya juga harus rata dan berbentuk bundar. Kemudian, dilanjutkan kembali penggalian lubang sebagai penyambung ke outlet dengan ukuran $1 \mathrm{~m}^{2}$ dan kedalaman $1.70 \mathrm{~m}$. Proses penggalian lubang tersebut berlangsung dalam tiga hari dengan dikerjakan oleh 4 kuli. Setelah penggalian lubang selesai, terdapat proses lanjutan dalam pembanguann instalasi biogas, seperti halnya pengecoran, pemasangan 
dinding digester, pelicinan dinding dan lantai, bekisting (pencetakan), pemasangan pipa gas hingga terbentuknya digester dan semua komponennya. Proses lanjutan tersebut sebagai berikut:

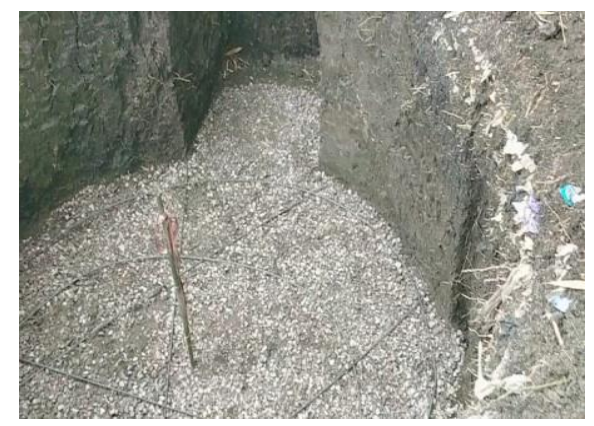

\section{Gambar 7. Proses Pengecoran Lantai}

Sumber: Dokumentasi Pribadi

Pada Gambar 7, telah dilakukan proses pengecoran lantai digester. Pengecoran lantai tersebut berfungsi sebagai pondasi dasar digester untuk mendukung digester dan kubah diatasnya semakin kuat. Kemudian, dilanjutkan proses pemasangan dan pelicinan dinding yang terlihat pada Gambar 8. Proses pemasangan batu bata dilakukan dengan ditata terlebih dahulu tanpa menggunakan adukan, dengan tujuan untuk memastikan ketepatan dalam pemasangan. Selanjutnya, pemasangan batu bata dilakukan dengan menggunakan adukan dan ketika susunan batu bata telah mencapai ketinggian tertentu, dipasanglah pipa inlet untuk mengalirkan hasil campuran dari kotoran sapi dengan air. Setelah proses pemasangan dinding selesai, dilanjutkan pelicinan dinding dengan menggunakan lapisan semen. Proses pemasangan batu bata dan pelicinan dinding sebagai berikut:
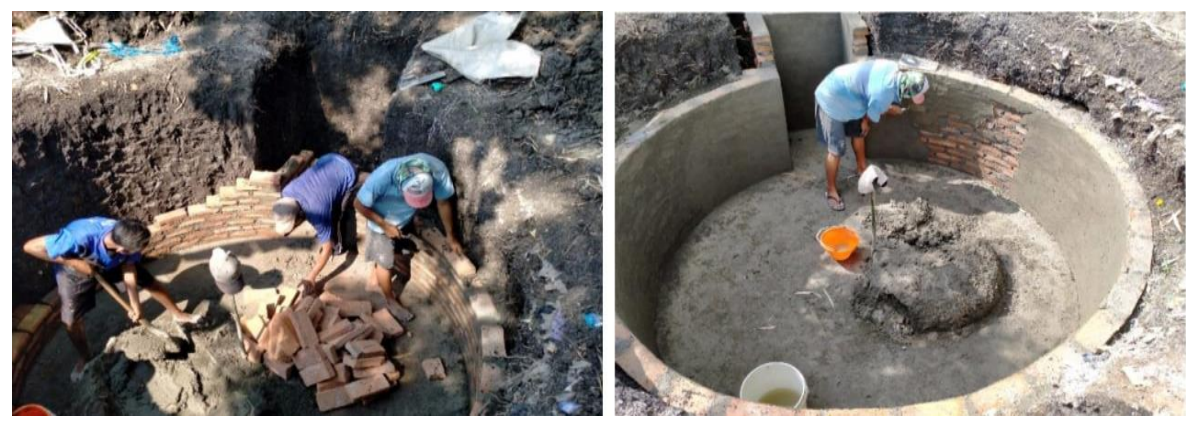

\section{Gambar 8. Proses Pemasangan dan Pelicinan Dinding}

Sumber: Dokumentasi Pribadi

Adapun pada Gambar 9, telah dilakukan proses bekisting (pencetakan). Proses bekisting yaitu bagian dalam digester diisi timbunan tanah yang dipadatkan. Berdasarkan literatur-literatur, tanah yang digunakan untuk proses pencetakan harus lembab, agar penyerapan air semen tidak terjadi. Kemudian, dilakukan pengecoran kubah dengan ketebalan yang telah ditetapkan. Pengecoran tersebut berfungsi sebagai fondasi dinding agar semakin kuat. Pengecoran harus dilakukan dengan cepat dan rapi tanpa berhenti, karena setiap jeda dalam waktu pengerjaan akan memberi dampak buruk untuk kualitas 
pengecoran (Model Instalasi Biogas, 2010). Proses bekisting (pencetakan) dan pengecoran kubah (penampung gas) sebagai berikut:

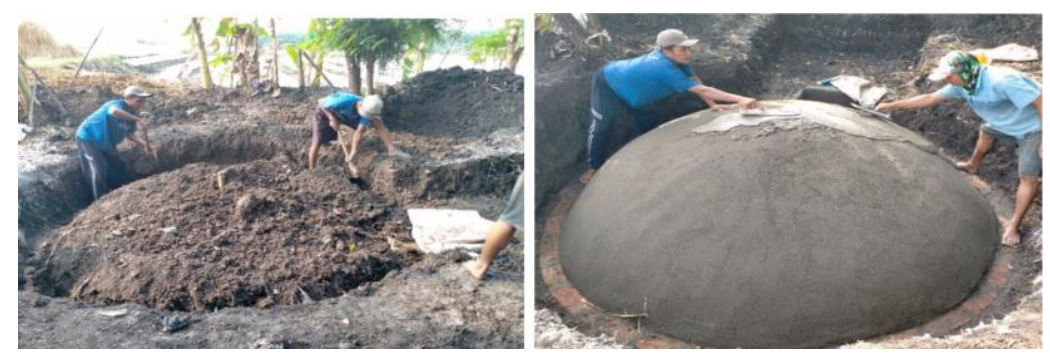

\section{Gambar 9. Proses Bekisting dan Pengecoran Kubah}

Sumber: Dokumentasi Pribadi

Setelah proses bekisting dan pengecoran selesai, dapat dilihat pada Gambar 10, telah dilakukan proses pemasangan pipa gas dengan posisi tepat ditengah-tengah kubah. Pipa gas utama sebagai penghubung antara reaktor dengan instalasi kompor biogas di dapur dan sebagai penyuplai gas dari hasil fermentasi di reaktor. Adapun proses pemasangan pipa gas dan tampilan digester biogas yang telah selesai dibangun terlihat pada Gambar 10 dan 11.

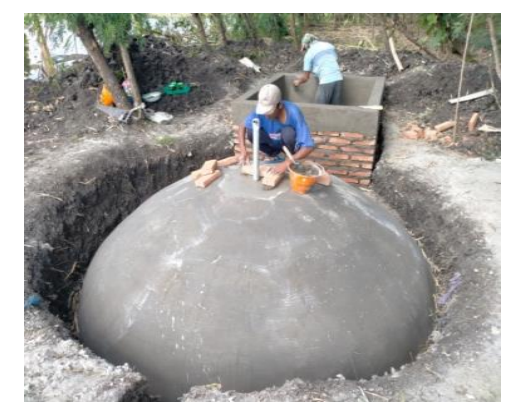

\section{Gambar 10. Pemasangan Pipa Gas}

Sumber: Dokumentasi Pribadi



\section{Gambar 11. Digester Biogas}

Sumber: Dokumentasi Pribadi

Selanjutnya, pada Gambar 12 dapat dilihat proses pembangunan inlet dan outlet. Pembangunan inlet berfungsi sebagai saluran masuk kotoran dan tempat untuk mencampur kotoran ternak sapi dengan air. Proses pembangunan inlet diawali dari dasar 
bangunan yang dibentuk lingkaran, dinding yang melingkar dibangun dengan menggunakan batu bata, dan ketika telah mencapai ketinggian tertentu batang pengikat mixer dipasang dan bersatu dengan bangunan inlet. Sedangkan proses pembangunan outlet pada bagian atasnya diberi lubang sebagai tempat mengalirnya limbah agar saluran keluarnya limbah dari digester semakin mudah. Menurut Tuwuilu dkk (2014) lubang pembuangan tersebut dibuat lebih rendah dari lubang pemasukan agar sisa limbah dapat ditekan keluar ketika penampung gas sudah terisi gas. Adapun tampilan instalasi biogas yang telah selesai dibangun terlihat pada Gambar 13.
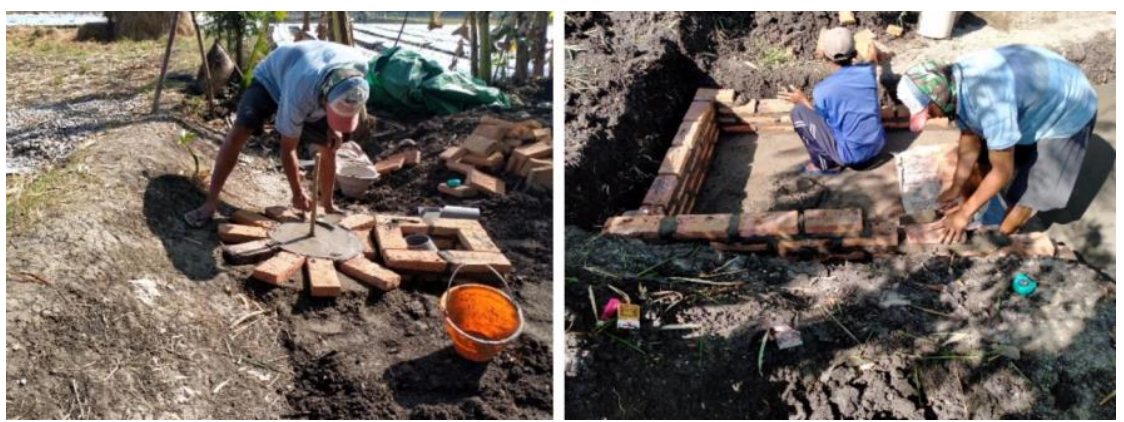

Gambar 12. Proses Pembangunan Inlet dan Outlet

Sumber: Dokumentasi Pribadi

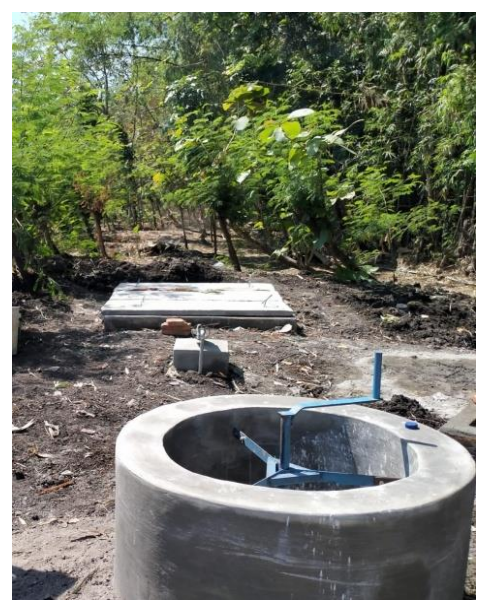

Gambar 13. Instalasi Biogas

Sumber: Dokumentasi Pribadi

Pada tahap ketiga, setelah selesai pembangunan instalasi biogas dilakukan pelatihan dalam mengolah limbah kotoran sapi menjadi biogas. Menurut Indawati, dkk (2016) untuk menghasilkan biogas, maka harus menyediakan terlebih dahulu material input berupa kotoran sapi. Selain itu, dalam proses pembentukan biogas diperlukan ruang yang kedap udara atau tertutup, dan hal ini menjadi suatu kelebihan sistem biogas dengan tidak adanya bau dari proses pengolahan biogas (Pratiwi dkk, 2019). Adapun langkah-langkah dalam pembuatan biogas menurut Razak \& Rahman (2018) adalah sebagai berikut:

1. Mencampur limbah kotoran sapi dengan air hingga terbentuk seperti lumpur dengan perbandingan 1:1 pada bak penampung (inlet). 
2. Mengalirkan campuran kotoran sapi dan air yang telah terbentuk lumpur kedalam digester melalui lubang inlet. Pada pengisian pertama dibutuhkan lumpur kotoran sapi dalam jumlah yang banyak hingga digester penuh.

3. Setelah digester penuh, kran gas harus ditutup agar terjadi proses fermentasi.

4. Pada hari ke-14 gas yang dihasilkan dapat digunakan untuk menyalakan api pada kompor gas, dan masyarakat dapat memanfaatkan untuk kebutuhan memasak. Selanjutnya, digester selalu diisi lumpur kotoran sapi secara kontinu agar menghailkan biogas yang optimal.

Pelatihan pengolahan limbah kotoran sapi menjadi biogas dilaksanakan pada hari Minggu, 30 Agustus 2020. Kegiatan pelatihan tersebut dilakukan oleh mitra yang ahli mengolah limbah sapi yaitu Bapak Sholihin dan dibantu oleh mahasiswa Ilmu Ekonomi Universitas Airlangga. Pelatihan tersebut meliputi cara-cara dalam pengisian bahan biogas, pengadukan kotoran sapi, dan segala tata cara terkait pengolahan limbah kotoran sapi. Selain itu, masyarakat petani juga dijelaskan tentang bagaimana cara merawat instalasi biogas dengan baik, agar tetap dapat digunakan untuk jangka yang lebih panjang dan terus dimanfaatkan oleh masyarakat petani di desa Jatitengah. Selama proses pelatihan, masyarakat petani sangat berantusias dan memperhatikan dengan baik proses pembuatan biogas.

Berdasarkan hasil wawancara dengan para petani di desa Jatitengah, diperoleh informasi bahwa masyarakat petani dan atau peternak sapi sangat mendukung adanya pembangunan instalasi biogas. "Kami merasa senang dan bersyukur dengan adanya program ini, karena hanya dengan memanfaatkan limbah kotoran sapi, maka kami bisa menghemat pengeluaran dalam pembelian gas LPG, apalagi sisa-sisa limbah tersebut juga bisa dimanfaatkan sebagai pupuk" ungkap beberapa petani di desa Jatitengah. Dengan demikian, adanya pembangunan instalasi biogas ini harapan kedepannya adalah biaya yang dikeluarkan para petani di desa Jatitengah menjadi lebih irit, karena tidak perlu membeli LPG, kemudian para petani dapat memanfaatkan secara maksimal bioslurry (ampas biogas), dan para petani lainnya lebih sadar bahwa limbah kotoran sapi dapat dimanfaatkan sebagai energi alternatif biogas, yang mendorong petani tersebut untuk membangun instalasi biogas, dan pada akhirnya para petani di desa Jatitengah akan menjadi lebih sejahtera.

\section{PENUTUP}

\section{Simpulan}

Secara keseluruhan kegiatan program pengabdian masyarakat di Desa Jatitengah telah dilaksanakan dengan baik dan masyarakat petani memberikan dukungan penuh atas terlaksananya program tersebut. Kegiatan pengabdian masyarakat ini telah berhasil dalam membangun instalasi biogas. Masyarakat petani dan peternak sapi di desa Jatitengah menjadi lebih paham dan mendapat pengetahuan baru tentang pemanfaatan limbah kotoran sapi, yang ternyata limbah kotoran sapi tersebut dapat menghasilkan energi alternatif biogas dan pupuk organik. Selain itu, adanya pemanfaatan limbah kotoran sapi sangat membantu masyarakat petani untuk menjaga kesehatan lingkungan, sehingga tidak mencemari lingkungan dan mengganggu masyarakat disekitarnya. Kegiatan program pengabdian masyarakat ini masih memiliki keterbatasan, antara lain dalam proses sosialisasi hanya dapat dilakukan oleh perwakilan masyarakat petani, karena mengingat kondisi saat ini di tengah pandemi, dan akhirnya terjadi 
kesalahpahaman antar masyarakat petani lainnya. Kemudian jarak antara tempat lokasi pengabdian dengan mitra yang ahli mengolah limbah sapi cukup jauh, sehingga sedikit sulit untuk memantau perkembangan.

\section{Saran}

Adapun saran dari kegiatan pengabdian masyarakat ini adalah diperlukan kegiatan lebih lanjut untuk mengembangkan instalasi biogas dalam lingkup yang lebih luas, agar para petani dan peternak sapi di sekitar desa Jatitengah menjadi terinspirasi untuk mengembangkan instalasi biogas di lingkungan mereka. Selain itu, perlu dilakukan juga program lanjutan untuk mengolah sisa limbah kotoran sapi menjadi pupuk organik cair maupun padat. Sehingga masyarakat petani desa Jatitengah dapat meningkatkan pendapatan ekonomi dan mendorong kesejahteraan keluarga.

\section{DAFTAR PUSTAKA}

Biogas Rumah (BIRU). (2010, Mei). Model Instalasi Biogas Indonesia: Panduan Konstruksi. Retrieved Agustus 21, 2020, from https://www.biru.or.id/alatinstalasi-biru

Choiron, M., \& Setiawan, A. (2015, Desember). Pendampingan Pemanfaatan Kembali Biogas dari Kotoran Sapi Pada Masyarakat di Desa Arjasa. Retrieved Januari $15,2019$.

Hamri, H., Hasan, I. and Altin, M. Z. (2019) 'Penerapan Alat Biogas Kotoran Sapi Program Kemitraan Masyarakat Kelompok Peternak Sapi Di Lanna Kecamatan Parangloe Kabupaten Gowa', in Seminar Nasional Hasil Penelitian \& Pengabdian Kepada Masyarakat (SNP2M), pp. 376-381.

Hastuti, D. (2009) 'Aplikasi Teknologi Biogas Guna Menunjang Kesejahteraan Petani Ternak', Mediagro, 5(1).

Indawati, N., Kusumawati, E. D., \& Susanto, W. E. (2016). "Pemanfaatan Limbah Kotoran Ternak Sapi Menjadi Biogas dan Pupuk Organik." Jurnal Pemberdayaan Masyarakat, 32-37.

Kamal, M., Waluyo, S., \& Kustiani, I. (2017). Pemberdayaan Civitas Akademika Dalam Pengelolaan Sampah Terpadu Universitas Lampung dan Pemanfaatan Mini Pembangkit Listrik Tenaga Biomassa.

Mahyudin, R. P. (2017) 'Kajian permasalahan pengelolaan sampah dan dampak lingkungan di TPA (Tempat Pemrosesan Akhir)', Jukung (Jurnal Teknik Lingkungan), 3(1), pp. 66-74.

Noerhayati, E. and Lesmanah, U. (2018) 'IbM Pemanfaatan Limbah Ternak Kelompok Tani Kedung Sumber Kab. Bojonegoro’ MASYARAKAT, 24(1), pp. 537-543.

Pratama, J. N. (2018, April). Tata Kelola Sampah di Kota Pekan Baru (Studi Kasus Pada Bank Sampah di Kota Pekan Baru Tahun 2016). 5. 
Pratiwi, I., Permatasari, R., \& Homza, O. F. (2019). Pemanfaatan Limbah Kotoran Ternak Sapi Dengan Reaktor Biogas di Kabupaten Ogan Ilir. IKRAITHABDIMAS, 2(3), 1-10.

Rahayu, S., Purwaningsih, D., \& Pujianto. (2009). "Pemanfaatan Kotoran Ternak Sapi Sebagai Sumber Energi Alternatif Ramah Lingkungan beserta Aspek Sosio Kulturalnya.” Jurnal Inotek, 13(2).

Razak, A., \& Rahman, A. (2018, Mei). Analisis Hasil Rancang Bangun Alat Produksi Biogas dengan Bahan Baku Kotoran Ternak. Retrieved Agustus 20, 2020, from researchgate:

https://www.researchgate.net/publication/332605072_ANALISIS_HASIL_RAN CANG_BANGUN_ALAT_PRODUKSI_BIOGAS_DENGAN_BAHAN_BAK U_KOTORAN_TERNAK

Suyanto, E., Soetarto, E., Sumardjo, \& Hardjomidjojo, H. (2015). Model Kebijakan Pengelolaan Sampah Berbasis Partisipasi "Green Community" Mendukung Kota Hijau. 143-152.

Tuwuilu, B., Rumambi, D., Rantung, R., \& Pinatik, H. (2014). "Uji Teknis Biogas Dari Bahan Baku Feses Sapi Di Desa Totabuan Kecamatan Lolak Kabupaten Bolaang Mongondow." Jurnal Unsrat.

Yanti, D., \& Arlius, F. (2018). Pemberdayaan Masyarakat tani Melalui Pengembangan Teknologi Biogas dengan Pemanfaatan Limbah Pertanian Sebagai Sumber Energi Alernatif Pedesaan. Jurnal Pengbdian Kepada Masyarakat. 